\title{
A COMPARATIVE EVAlUATION OF CIMETIDINE AND SODIUM CITRATE TO DECREASE GASTRIC ACIDITY: EFFECTIVENESS AT THE TIME OF INDUCTION OF ANAESTHESIA
}

\author{
ELLEN FOULKES ANd L.C. JENKINS
}

\begin{abstract}
Patients coming for elective surgery were randomly assigned to one of three treatment groups: control, cimetidine $300 \mathrm{mg}$ orally two hours pre-operatively, or sodium citrate $0.3 \mathrm{M}$ solution $30 \mathrm{ml}$ orally, given as the patient was leaving the ward for the operating room. Each group consisted of 15 patients. This study reconfirms the average 26 per cent risk of significant aspiration in patients, coming for elective surgery, who have not received an agent intended to decrease gastric acidity or to decrease volume of gastric content. Sodium citrate is effective most of the time ( 87 per cent) in decreasing gastric acidity but is associated with a large mean volume $(40.8 \mathrm{ml})$ of aspirate. From the results of this study cimetidine appears to be the preferable agent to use because it is completely effective in decreasing gastric acidity but does not increase the mean volume $(17.0 \mathrm{ml})$ of the aspirate. Cimetidine appears to be an excellent agent to use as a preventative measure against aspiration during the induction of anaesthesia. Sudium citrate is a reasonable alternative if there is a contraindication to the use of cimetidine. However, these agents should be regarded only as adjuncts in the prevention of aspiration of gastric contents at the time of induction of anaesthesia.
\end{abstract}

KEY WORDS: GASTRIC ACIDITY, cimetidine, sodium citrate.

IN 1946, Mendelson first described the syndrome of pulmonary aspiration of gastric contents in obstetrical patients undergoing general anaesthesia. ${ }^{1}$ There has been ongoing research to elucidate the significance of the acidity of the aspirate, the volume of the aspirate and how to alter one or both of these. The syndrome of aspiration pneumonitis has been reproduced in the laboratory situation by instilling clear solutions of acid or filtered gastric contents with a hydrogen ion concentration $\left(\left[\mathrm{H}^{+}\right]\right)$greater than $3.16 \times 10^{-3}$ milliequivalents per litre ( $\mathrm{mEq} / \mathrm{l})$ into the lungs. ${ }^{1,2}$ When the $\left[\mathrm{H}^{+}\right]$of the aspirate was less than 3.16 $\times 10^{-3} \mathrm{mEq} / 1$ (pH greater than 2.5) the physiological and morphological responses were slight and transient. The volume of aspirated gastric acid necessary to produce a significant pulmonary reaction in man is unknown. Based on work done by Roberts and Shirley ${ }^{3}$ with Rhesus monkeys the suggested minimum volume which may be hazardous is $0.4 \mathrm{ml} / \mathrm{kg}$ or, on the average, $25 \mathrm{ml}$.

Animal and human data to the present time implicate the acidity of gastric contents as the most important causative factor in the develop-

Ellen Foulkes, M.D., L.C. Jenkins, M.D. F.R.C.P.(C), Department of Anaesthesia, University of British Columbia, Vancouver General Hospital, Vancouver, Canada, V5Z 1 M9.

Canad. Anaesth. Soc. J., vol. 28, no. 1, January 1981 ment of aspiration pneumonitis. Volume of fluid aspirated appears to be secondary to acidity as a cause of pneumonitis, primarily being of significance in the presence of a high $\left[\mathrm{H}^{+}\right]$.

As aspiration of gastric contents is a recognized complication of a depressed level of consciousness, the aim of the study was to find an easily administered, effective way of decreasing gastric acidity so that it is below $3.16 \times 10^{-3}$ $\mathrm{mEq} / \mathrm{l}$ (above $\mathrm{pH} 2.5$ ) at the time of induction of anaesthesia.

Two agents, cimetidine, a histamine- $\mathrm{H}_{2}$ receptor antagonist which decreases $\mathrm{H}^{+}$secretion into gastric fluid and sodium citrate, a clear alkaline solution ( $\mathrm{pH}=8.21$ ), were studied with respect to their effectiveness in decreasing gastric acidity and with respect to their effect on gastric volume in patients coming for elective surgical procedures.

\section{Methods and Materials}

Patient selection was limited to 45 adults (age 19 to 70 years), ASA Class I or II, non-pregnant, with no gastrointestinal pathology and coming for elective surgical procedures. They were randomly assigned to one of three equal size $(n=15)$ treatment groups: control, cimetidine or sodium citrate. 
TABLE I

SUMMARY OF RESULTS OF $\left[\mathrm{H}^{+}\right]$AND VOLUME

\begin{tabular}{|c|c|c|c|c|c|}
\hline & $\begin{array}{c}{\left[\mathrm{H}^{+}\right]>\underset{ }{3.16 \times 10^{-3} \mathrm{mEq} / \mathrm{l}}} \\
(\mathrm{pH}<2.5)\end{array}$ & $\begin{array}{l}{\left[\mathrm{H}^{+}\right] \text {Mean }} \\
(\mathrm{pH} \text { Mean })\end{array}$ & $\begin{array}{l}\text { Standard } \\
\text { Deviation }\end{array}$ & $\begin{array}{l}\text { Volume } \\
\text { Aspirated } \\
>25 \mathrm{cc}\end{array}$ & $\begin{array}{c}{\left[\mathrm{H}^{+}\right]>3.16 \times 10^{-3} \mathrm{mEq} / 1} \\
(\mathrm{pH}<2.5) \text { and Volume } \\
>25 \mathrm{cc}\end{array}$ \\
\hline $\begin{array}{l}\text { Control } \\
(n=15)\end{array}$ & $12(80 \%)$ & $\begin{array}{c}3.63 \times 10^{-3} \mathrm{mEq} / 1 \\
(2.44)\end{array}$ & 1.60 & $5(34 \%)$ & $4(26 \%)$ \\
\hline $\begin{array}{l}\text { Na citrate } \\
0.3 \mathrm{M} \text { sln } \\
(\mathrm{n}=15)\end{array}$ & $2(13 \%)$ & $\begin{array}{c}2.63 \times 10^{-6} \mathrm{mEq} / \mathrm{l} \\
(5.58)\end{array}$ & 1.89 & $13(87 \%)$ & 0 \\
\hline $\begin{array}{l}\text { Cimetidine } \\
300 \mathrm{mg} \text { po } \\
(\mathrm{n}=15)\end{array}$ & 0 & $\begin{array}{c}9.12 \times 10^{-6} \mathrm{mEq} / 1 \\
(5.04)\end{array}$ & 1.86 & $3(20 \%)$ & 0 \\
\hline
\end{tabular}

TABLE II

Summary of ANalysis of Variance $(\mathrm{pH})$

\begin{tabular}{lrcc}
\hline \multicolumn{1}{c}{ Source } & df & Mean squares & F ratio* \\
\hline Treatments & 2 & 42.10 & 13.17 \\
Within Groups & 42 & 3.20 & \\
Total & 44 & & \\
\hline
\end{tabular}

$*_{p}<0.01$.

SUMmary of ANalysis of Variance (Volume)

\begin{tabular}{lrcr}
\hline \multicolumn{1}{c}{ Source } & df & Mean squares & F ratio* \\
\hline Treatments & 2 & 2704.95 & 11.72 \\
Within Groups & 42 & 230.73 & \\
Total & 44 & & \\
\hline
\end{tabular}

${ }^{*} \mathrm{p}<0.01$.

Each patient received premedication as ordered by the attending anaesthetist consisting of a benzodiazepine per os (p.o.) or a narcotic with or without atropine or hyoscine intramuscularly (I.M.). The groups were similar with regard to distribution of type of pre-anaesthetic medication. Patients in the control group received no additional agents. Cimetidine was administered as $300 \mathrm{mg}$ p.o., two hours before operation. Sodium citrate $0.3 \mathrm{M}$ solution, $30 \mathrm{ml}$ p.o. was given as the patient was leaving the ward for the operating room.

After induction of anaesthesia and tracheal intubation a number 14 Salem sump gastric tube was inserted orally into the stomach and the contents aspirated until dry. Volume aspirated was recorded and the $\mathrm{pH}$ was measured using a Radiometer Copenhagen pH meter.

\section{Results}

\section{Control Group (Table I)}

Twelve ( 80 per cent) of the fifteen patients in the control group, had measured $\left[\mathrm{H}^{+}\right]$greater than $3.16 \times 10^{-3} \mathrm{mEq} / \mathrm{l}(\mathrm{pH}<2.5)$. Of this group of twelve, four ( 34 per cent) had aspirated volumes in excess of $25 \mathrm{ml}$. Overall four patients of the fifteen ( 26 per cent) had $\left[\mathrm{H}^{+}\right]$greater than 3.16 $\times 10^{-3} \mathrm{mEq} / \mathrm{l}(\mathrm{pH}<2.5)$ and a measured volume greater than $25 \mathrm{ml}$. The mean $\left[\mathrm{H}^{+}\right]$of the group was $3.63 \times 10^{-3} \mathrm{mEq} / \mathrm{l}(\mathrm{pH} 2.44)$, while the mean measured volume was $18.3 \mathrm{ml}$.

\section{Sodium Citrate Group (Table I)}

In this group of patients only two ( 13 per cent) had a $\left[\mathrm{H}^{+}\right]$greater than $3.16 \times 10^{-3} \mathrm{mEq} / 1(\mathrm{pH}<$ 2.5 ), but the volume of aspirate was markedly increased with thirteen ( 87 per cent) patients having more than $25 \mathrm{ml}$ measured. The two patients with the high $\left[\mathrm{H}^{+}\right]$were also the only ones without a significant measured volume. The mean $\left[\mathrm{H}^{+}\right]$was $2.63 \times 10^{-6} \mathrm{mEq} / \mathrm{l}(\mathrm{pH} \mathrm{S.58)}$, and the mean measured volume was $40.8 \mathrm{ml}$.

\section{Cimetidine Group (Table I)}

None of the patients in this group had a measured $\left[\mathrm{H}^{+}\right]$greater than $3.16 \times 10^{-3} \mathrm{mEq} / \mathrm{l}(\mathrm{pH}<$ $2.5)$. The range was from $1.54 \times 10^{-3} \mathrm{mEq} / \mathrm{l}(\mathrm{pH}$ $2.81)$ to $2.45 \times 10^{-8} \mathrm{mEq} / \mathrm{l}(\mathrm{pH} 7.61)$ with a mean $\left[\mathrm{H}^{+}\right]$of $9.12 \times 10^{-6} \mathrm{mEq} / \mathrm{l}(\mathrm{pH} 5.04)$. Only three (20 per cent) had volumes in excess of $25 \mathrm{ml}$. Volume measured ranged from 3 to $54 \mathrm{ml}$ with a mean of $17.0 \mathrm{ml}$.

One cannot assume that the stomach has been completely emptied by aspirating through a gastric tube; therefore, the measured volume may underestimate the true amount present. The vol- 
ume as measured here is pertinent only as an indicator of minimum volume in the stomach.

The data obtained were submitted to statistical analysis using one-way analysis of variance followed, where appropriate, with the Tukey HSD procedure. $^{4}$

The two dependent variables were treated separately at the 0.01 level of significance. As shown in Table II, significant differences among mean $\left[\mathrm{H}^{+}\right]$and mean volume were found. Application of Tukey's procedure revealed that both cimetidine and sodium citrate were effective in decreasing acidity below control levels. Sodium citrate produced a significantly larger volume of aspirate than either cimetidine or the controls.

\section{Discussion}

Gastric fluid with a $\left[\mathrm{H}^{+}\right]$greater than $3.16 \times$ $10^{-3} \mathrm{mEq} / \mathrm{l}(\mathrm{pH} \leq 2.5)$ has been implicated as the primary causative factor in aspiration pneumonitis. The logical prophylaxis for aspiration pneumonitis was to use commercial antacid preparations to decrease gastric acidity. The use of $15 \mathrm{ml}$ antacid p.o. 30 to 90 minutes before operation became common until 1975. At that time Taylor published a case report of pulmonary complications following aspiration of gastric contents with $\left[\mathrm{H}^{+}\right]$of $3.16 \times 10^{-4} \mathrm{mEq} / \mathrm{l}(\mathrm{pH} 3.5)$ in a patient who had received antacids. ${ }^{5}$ As a result, the recommendation was to increase the volume of pre-operative antacid to $30 \mathrm{ml}$. Further research by Gibbs has shown that this practice is likely dangerous. ${ }^{6}$ Working with dogs, he showed that the aspiration of particulate antacids causes at least as much pulmonary damage as does the aspiration of gastric acid and the effects of antacids on the lungs are greatly prolonged. ${ }^{6}$ The laboratory work does have clinical relevance based on case reports of pulmonary problems following the aspiration of gastric contents containing antacids. ${ }^{7.8}$

There are alternatives to the use of particulate antacids. One of the alternatives is sodium citrate $0.3 \mathrm{M}$ solution which has variously been reported as being effective and non-effective in diminishing gastric acidity. ${ }^{9.10}$ Sodium citrate solution at least produces minimal insult when it is instilled into the lungs.

Another alternative is the use of histamine $\mathbf{H}_{2}$ receptor antagonists, such as cimetidine, which inhibit gastric secretion and thereby decrease acidity. There have been conflicting reports re- garding its efficacy in accomplishing this aim at the time of induction of anaesthesia. 11,12

Other agents have been investigated for their ability to protect against aspiration pneumonitis. Metoclopramide has no effect on gastric acidity, but it has been shown to increase gastric emptying by increasing peristalsis and relaxing the pyloric sphincter. ${ }^{13}$ It also increases the tone of the lower oesophageal sphincter. ${ }^{14}$ Anticholinergic drugs have also been investigated, but in common clinical doses they have no effect on gastric $\mathrm{pH}^{15}$ and they decrease lower oesophageal sphincter tone, ${ }^{16}$ increasing the risk of regurgitation.

In summary, on the basis of the data collected here 26 per cent of patients coming for elective surgery who have not received an agent intended to decrease gastric acidity are at risk of significant pulmonary aspiration. Cimetidine and sodium citrate $0.3 \mathrm{M}$ solution are equally effective in decreasing mean gastric $\left[\mathrm{H}^{+}\right]$significantly below that of the control group as determined by the Tukey HSD procedure. Sodium citrate $0.3 \mathrm{M}$ solution as used in this study produces a significantly greater mean volume of aspirate than that of the cimetidine and control groups as determined by the Tukey HSD procedure. The more satisfactory agent appears to be cimetidine $300 \mathrm{mg}$ p.o. two hours before operation. In this study it was 100 per cent effective in decreasing gastric $\left[\mathrm{H}^{+}\right]$below $3.16 \times 10^{-3} \mathrm{mEq} / \mathrm{l}(\mathrm{pH}>2.5)$ and it did not increase gastric volume.

\section{ACKNOWLEDGEMENTS}

A special note of appreciation to Dr. Todd Rogers, University of British Columbia for his aid in the statistical analysis of the data.

Dr. L. Davies, Dr. P. Hudson and Dr. M. Miller were particularly helpful in assisting with the clinical procedures.

\section{REFERENCES}

1. Mendelson, C.L. The aspiration of stomach contents into the lungs during obstetric anaesthesia. Am. J. Obstet. Gynecol. 52: 191-205, 1946.

2. Teabeaut, J.R. II. Aspiration of gastric contents. An experimental study. Am. J. Pathol. 28: 51-67, 1952.

3. Roberts, R.B. \& Shirley, M.A. Reducing the risk of acid aspiration during caesarean section. Anesth. Analg. (Cleve) 53: 859-868, 1974.

4. Glass, G.V. \& Stanley, J.C. Statistical methods in education and psychology, 1st ed. Englewood Cliffs, New Jersey: Prentice-Hall (1970). 
5. TAYLOR, G. Acid pulmonary aspiration syndrome after antacids. Br. J. Anaesth. 47: 615-616, 1975.

6. GibBs, C.P., Schwartz, D.J., Wynne, J.W. et al. Antacid pulmonary aspiration in the dog. Anesthesiology 51: 380-385, 1979.

7. Bond, V.K., Stoelting, R.K. \& Gupta, C.D. Pulmonary aspiration syndrome after inhalation of gastric fluid containing antacids. Anesthesiology 51: 452-453, 1979

8. Heaney, G.A.H. \& Jones, H.D. Aspiration syndromes in pregnancy (correspondence). $\mathrm{Br} . \mathrm{J}$. Anaesth. 5I: 266-267, 1979

9. LAHIRI, D.K., ThOMAS, T.A. \& Hodgson, R.M.H. Single dose antacid therapy for the prevention of Mendelson's syndrome. Br. J. Anaesth. 45: 1143-1146, 1973.

10. Hester, J.B. \& Heath, M.L. Pulmonary acid aspiration syndrome: Should prophylaxis be routine? Br. J. Anaesth. 49: 595-599, 1977.

11. Stoelting, R.K. Gastric fluid $\mathrm{pH}$ in patients re- ceiving cimetidine. Anesth. Analg. (Cleve) 57: 675-677, 1978.

12. Pickering, P.G., Palahniuk, R.J. \& Cumming M. Cimetidine premedication in elective caesarean section. Canad. A naes. Soc. J. 27: 33-35, 1980.

13. Howard, F.A. \& SHARP, D.S. Effect of metoclopramide on gastric emptying during labor. $\mathrm{Br}$. Med. J. $1: 446-448,1973$.

14. Brock-Utne, J.G., Dow, T.G.B., Welman, S. et al. The effects of metoclopramide on the lower esophageal sphincter in late pregnancy. Anesth. Intens. Care 6: 26-29, 1978.

15. Stoelting, R.K. Responses to atropine glycopyrrolate and Riopan of gastric fluid $\mathrm{pH}$ and volume in adult patients. Anesthesiology 48: $367-369,1978$

16. Dow, T.G.B., Brock-UtNe, J.G., Welman, S. et al. The effect of atropine on the lower esophageal sphincter in late pregnancy. Am. J. Obstet. Gynecol. 1977.

\section{RÉSUMÉ}

Quelques patients devant subir une chirurgie réglée ont été répartis au hasard en trois groupes: contrôle, cimétidine $300 \mathrm{mg}$ par la voie orale deux heures avant l'intervention, citrate de soude $0.3 \mathrm{M} 30 \mathrm{ml}$ par la voie orale administré au patient au moment où il quitte sa chambre pour la salle d'opération. Chaque groupe comprenait 15 patients. Cette étude confirme de façon significative le risque d'aspiration (en moyenne de 26 pour cent) pour les patients qui se présentent en chirurgie réglée et qui n'ont rien reçu pour diminuer l'acidité ou le volume du contenu gastrique. Le citrate de soude est efficace la plupart du temps (à 87 pour cent) pour diminuer l'acidité gastrique mais conduit à une augmentation importante du volume $(40.8 \mathrm{ml})$. A partir de cette étude qui montre sa complète efficacité, on conclut que la cimétidine pourrait être préférable au citrate de soude car elle produit une diminution de l'acidité gastrique sans augmentation du contenu moyen $(17.0 \mathrm{ml})$. La cimétidine serait donc l'agent de choix à utiliser comme préventif contre l'aspiration durant l'induction de l'anesthésie. Le citrate de soude est une alternative raisonnable s'il y a contre-indication à l'emploi de la cimétidine. Cependant, ces agents ne devraient être regardés que comme des drogues d'appoint pour la prévention de l'aspiration du contenu gastrique pendant l'induction de l'anesthésie. 